\title{
RELIGIÃO, PLURALISMO E ESFERA PÚBLICA NO BRASIL
}

\author{
PAUlA MONTERO
}

\begin{abstract}
RESUMO
Conforme formulado por Weber, a força secularizadora da ética protestante teria promovido uma forma subjetivada de experiência religiosa. Da mesma maneira, a reforma protestante teria aprofundado o processo de diferenciação das esferas político-econômico-científicas em relação à religiosa, o que retiraria definitivamente a religião do espaço público. À luz de dados relativos ao campo religioso brasileiro, são essas as duas premissas discutidas neste artigo. Em vez de admitir como um pressuposto a privatização da prática religiosa, trata-se de identificar as configurações específicas que as formas religiosas assumem em cada sociedade.
\end{abstract}

PALAVRAS-CHAVE: campo religioso brasileiro; Igreja católica; sociedade civil; Igreja Universal.

\section{SUMMARY}

As stated by Weber, the secularization power of the Protestant ethic would have led to a subjective form of religious experience. In the same direction, the Protestant Reformation would have made more intense the differentiation process of political, economic and scientific spheres in relation to the religious sphere. This would have resulted in the withdrawal of religion from the public space. Taking the religious field in Brazil as an example, this article puts these premises into question. Instead of taking the privatization of religious pratic as a given reality, one should identify the specific configurations assumed by religious forms on each society.

KEYWORDS: religious field in Brazil; Catholic Church; civil society; Universal Church.

[1] Cf.Weber, Max.Laéticaprotestantey el espíritu del capitalismo. Barcelona: Península, 1969 [1904]; Tambiah, Stanley J. Magic, science, religion ad the scope of rationality. Cambridge University Press, 1990; Casanova, José. Public religions in the modern world. Chicago: University of Chicago Press, 1994.

[2] Weber, Max.Ensaios de sociologia. 5 a ed. Rio de Janeiro: Guanabara, 1982 [1913], p.325.
A idéia de que a religião se constitui como fenômeno socioantropológico no processo histórico da modernização do Ocidente já foi de tal modo trabalhada pela literatura que hoje pode ser considerada consensual'. O paradigma weberiano da "secularização" deu a essa noção sua formulação mais analítica. Como se sabe, segundo esse paradigma interpretativo a objetivação da religião como uma esfera diferenciada da vida social é fruto de um movimento histórico inaugurado pela modernidade exponencialmente estimulado pelo ascetismo protestante. Para Weber, as religiões éticas, caracterizadas pela sua concepção abstrata da salvação, teriam sido responsáveis pela racionalização da imagem de um mundo sem Deus e pela projeção da experiência mística para o além². 
Duas conseqüências desse processo de desmistificação da experiência religiosa são freqüentemente reiteradas pela literatura como conquistas históricas irreversíveis: por um lado, a força secularizadora da ética protestante teria promovido uma forma subjetivada de experiência religiosa; por outro, a reforma protestante, conjugada à emergência dos Estados modernos e da ciência, teria aprofundado o processo de diferenciação das esferas político-econômico-científicas em relação à religiosa, o que retiraria definitivamente a religião do espaço público. À luz de dados relativos ao campo religioso brasileiro, são essas duas premissas que gostaríamos de discutir neste trabalho. Antes, porém, convém expor mais claramente os termos do problema.

Embora a emancipação da esfera secular das instituições religiosas tenha sido um resultado iniludível do processo de modernização que culminou com a separação jurídica entre Estado e Igreja, alguns autores criticam a dimensão normativa do paradigma weberiano da secularização. Segundo José Casanova,

uma vez que a secularização foi concebida como um processo teleológico universal cujo resultado era conhecido de antemão (o declínio religioso e sua privatização), os cientistas sociais não se interessaram em estudar os diferentes caminhos que as sociedades tomam ${ }^{3}$.

[3] Casanova, op.cit., p.25.

Em artigo anterior retomei essa crítica aos usos e abusos do conceito de secularização, procurando demonstrar que sua dimensão prescritiva o torna inútil para a teoria social, uma vez queé despropositada a pretensão de "medir" o quanto de secularização existe em uma sociedade 4 . Neste ensaio procuro avançar um pouco nessa direção, pontuando as particularidades desse processo de diferenciação no caso brasileiro.

Embora a diferenciação das esferas sociais certamente constitua uma dimensão fundamental da ordem social moderna, não pode ser reduzida a um movimento de simples retração do religioso. Vários autores têm demonstrado que a secularização é apenas um dos elementos de um processo histórico amplo, que inclui a emergência de um mercado impessoal, de um Estado mais distante da regulação moral, de uma vida intelectual que dispensa a idéia de Deus e de uma experiência de individuação urbana mais escolarizada e autônoma. O viés do legado protestante implícito no paradigma da secularização faz da emergência da sociedade civil uma extensão da lógica secularizadora do próprio protestantismo.

Ora, autores como Habermas mostram que é possível prescindir do paradigma da secularização para pensar o processo de diferenciação das esferas, em particular a emergência da distinção "esfera pública/esfera privada". Segundo Habermas, embora a distinção grega entre cité (esfera da pólis) e oikos (esfera doméstica) tenha chegado até nós como um modelo, só encontrou aplicação efetiva na prática do direito com a aparição do Estado moderno e de uma esfera civil 5 . Dessa forma, uma das

[5] Habermas, Jürgen. L'espace public. Paris: Payot, 1978.

[4] Montero, Paula. "Max Weber e os dilemas da secularização”. Novos Estudos, no 65, 2003, p. 36 . 
[6] Não há consenso na análise social acerca da terminologia mais adequada para distinguir o público do privado. Segundo Casanova (op. cit., p. 42), na tradição política liberal a distinção sempre foi referida à separação constitucional entre Estado e Igreja; o republicanismo clássico reduz o público ao governamental; o campo históricoantropológico trata a esfera da sociabilidade como esfera pública; e o ponto de vista das feministas opõe a família ao mercado. Para o autor, os desacordos advêm da dificuldade de encaixar a estrutura tripartite "Estado/família/sociedade civil" numa oposição binária que deriva da antiga oposição grega. A esfera da sociedade civil, que articula as outras duas, cria interpenetrações variadas entre elas. Na interpretação de Sérgio Costa (As cores de Ercília. Belo Horizonte: Ed. UFMG, 2002, p. 27), para Habermas não há distinção apriorística entre o público e o privado, já que a esfera pública "é ubíqua, perpassando todos os níveis da sociedade e incorporando todos os discursos, visões de mundo e interpretações que adquirem visibilidade e expressão pública".

[7] Casanova,op.cit., p.90. diferenciações mais importantes para a compreensão da ordem social moderna, para além da separação entre Estado e Igreja, é a distinção entre a esfera pública do Estado e a esfera privada da sociedade. Eé nesse sentido que a religião se torna uma questão privada: ela é excluída da esfera do Estado.

Mas o processo de diferenciação não termina aí. Habermas aponta que a partir do século XVIII emerge uma outra distinção, representada pela esfera das pessoas privadas reunidas em um público, a esfera pública burguesa ou sociedade civil, que tem como conseqüência mais expressiva a interiorização da família no espaço privado. Ainda que, segundo o autor, a sociedade de massa tenha fragilizado os fundamentos da esfera pública, turvando as distinções entre o público e o privado, parece-me que se tomarmos essa concepção tripartite - Estado/sociedade/esfera privada - como intrínseca à ordem social moderna o problema das relações entre religião e sociedade pode ser proposto em termos analíticos mais adequados e não-normativos: em vez de admitir como um pressuposto a privatização da prática religiosa - seu confinamento à esfera familiar - , trata-se de identificar as configurações específicas que as formas religiosas assumem em cada sociedade em função de seus modos particulares de produzir historicamente a diferenciação dessas esferas e articulá-las ${ }^{6}$. No Brasil, como veremos mais adiante, o processo que levou à separação entre Estado e Igreja alocou a religião na sociedade civil.

Como bem observou Casanova, não resta dúvida de que a liberdade religiosa, entendida como liberdade de consciência, "foi cronologicamente a 'primeira liberdade' e por conseguinte a precondição de todas as liberdades modernas". Da mesma maneira, o "direito à privacidade", fundamento do liberalismo moderno, depende das garantias conferidas à liberdade de consciência7. A liberdade de consciência e o direito à privacidade são, pois, os direitos fundadores e legitimadores do Estado liberal moderno. No entanto, essa constatação é apenas um ponto de partida. Do contrário, o problema das relações entre religião e sociedade seria reduzido à questão de uma separação institucional juridicamente perfeita entre Estado e Igreja.

É possível arrolar os mais diversos exemplos históricos para demonstrar que a emergência de Estados seculares não tem como decorrência necessária e mecânica a privatização da religião na esfera doméstica. Na verdade, o direito inviolável à privacidade e a liberdade de consciência são condições modernas que às próprias religiões interessa preservar. Veremos a seguir que é exatamente em nome desses direitos que se constitui historicamente, na primeira metade do século XX, o pluralismo religioso brasileiro. No processo de constituição do nosso Estado moderno como esfera política própria, ao passo que houve um retraimento do catolicismo para o espaço social, produziu-se um intenso conflito em torno da autonomia de certas manifestações culturais de matriz não-cristã, ou da sua legitimidade para expressar-se 
publicamente. Assim, no processo mesmo de constituição do Estado brasileiro como esfera separada da Igreja Católica, manifestações variadas de "feitiçaria", "curandeirismo" e "batuques" só puderam ser descriminalizadas quando, em nome do direito à liberdade de culto, passaram a se constituir institucionalmente como religiões.

Procuraremos demonstrar que no Brasil o processo de diferenciação das esferas sociais não implicou a erradicação da magia, mas uma forma particular de enquadramento daquilo que era percebido como "magia" naquilo se convencionava chamar de "religião", cujo modelo de referência era o cristianismo. Buscaremos ainda mostrar que tal processo não redundou na retirada das religiões do espaço público: ao contrário, resultou na produção de novas formas religiosas, com expressão pública variável conforme o contexto e as suas formas específicas de organização institucional. Argumentaremos que o compromisso normativo resultante do movimento de produção de novas institucionalidades religiosas - em meio a um conflituoso debate público em torno do que poderia ser ou não compreendido como "mágico" e dos seus efeitos sobre a ordem social - nunca levou a uma desmistificação da experiência religiosa (seja nos termos do tipo ideal weberiano da ética protestante, seja nos termos práticos e políticos da Igreja Católica) capaz de promover, de maneira generalizada, formas religiosas subjetivadas.

\section{PLURALISMO RELIGIOSO}

Aliteratura sobre o campo religioso brasileiro tem demonstrado que as fronteiras institucionais que distinguem as religiões não-católicas entre si resultam de um processo histórico de alianças e conflitos entre atores religiosos e não-religiosos ${ }^{8}$. Nesse processo, as formas religiosas foram se constituindo e se modificando em função de um jogo de forças que opôs a eficácia simbólica daquilo que contextualmente fosse definido como mágico e a legitimidade social do que fosse assumido como religioso. Assim, embora as análises antropológicas mais recentes tendam a fixar essas cosmovisões e seus rituais como inerentes às identidades religiosas - supondo implicitamente que essas práticas já nasceram como "religiões" definidas - , pode-se perceber a partir dos dados históricos apresentados pela literatura que as particularidades dos contextos locais, as personalidades e as trajetórias dos agentes mediadores que procuram institucionalizar certas práticas e os limites colocados pelas diretrizes jurídico-políticas do Estado promoveram arranjos muitas vezes difíceis de enquadrar nas tipologias religiosas produzidas pelos modelos acadêmicos, como veremos adiante?.

A questão que devemos nos colocar em primeiro lugaré aquela proposta por Giumbelli em seu estudo sobre o espiritismo ${ }^{10}$ : a partir de quais critérios um momento histórico reconhece algo como religião? Dito de outro modo: onde, quando e por quem os sistemas classificatórios são inventados e de que maneira adquirem legitimidade para serem
[8] Cf. Giumbelli, Emerson A. O cuidadodos mortos:uma história da condenação > e legitimação do espiritismo. Rio de Janeiro: Arquivo Nacional, 1997; Dantas, Beatriz G. Vovó Nagô e Papai Branco: usos e abusos daÁfrica no Brasil. São Paulo: Graal, 1988; Maggie, Yvonne. Medo do feitiço: relações entre magia e poder no Brasil. Rio de Janeiro: Arquivo Nacional, 1992; Negrão, Lísias. Entre a cruz e a encruzilhada: formação do campo umbandista em São Paulo. São Paulo: Edusp, 1996; Schritzmeyer, Ana Lúcia P. Sortilégios de saberes: curandeiros e juízes nos tribunais brasileiros. São Paulo: Instituto Brasileiro de Ciências Criminais, 2004.

[9] Roger Bastide foi um dos primeiros autores a conferir essa dimensão histórico-simbólica ao problema do sincretismo. Segundo ele, não são as "civilizações" que entram em contato, mas "seres humanos" com desejos de prestígio, distinção, ascensão social. Bastide enfatiza que os "empréstimos" são mentais e não se manifestam fora dos limites da experiência dos indivíduos em situação. Assim, sua antropologia propõe metodologicamente a comparação entre configurações sincréticas distintas em diferentes momentos e lugares. Embora sua proposta possa ser considerada um avanço importante em relação às abordagens culturalistas anteriores, o autor não conseguiu realizar plenamente seu programa teórico, talvez porque tenha concebido uma "civilização africana" anterior e definível de maneira autônoma quanto às relações sócio-históricas que a construíram no Brasil.Cf. Bastide, Roger. The African religion of Brazil: toward a socio$\log y$ of the interpenetration of civilizations. Baltimore: John Hopkins University Press, 1978 [1960].

[10] Giumbelli, op.cit., p.29. 
[11] Schritzmeyer, op. cit. Segundo Emerson Giumbelli (O fim da religião: controvérsias acerca das "seitas" e da "liberdade religiosa" no Brasil e na França. Rio de Janeiro: tese de doutorado, Museu Nacional, 2000, p. 217), a Constituição de 1891 é a base da ordenação jurídica do estatuto da religião na República; as constituições posteriores trouxeram apenas alguns acréscimos e qualificações.

[12] Maggie,op.cit.
[13] Embora Pedro II tenha encorajado a vinda de missionários protestantes ao Brasil, estes não exerceram influência expressiva nas disputas em torno das liberdades religiosas. Durante o Império, os protestantes estiveram associados sobretudo às comunidades de imigração, no início basicamente alemãs. No séculoXX, por influência norte-americana, batistas e metodistas se difundiram de maneira mais ou menos intensa, constituindo ilhas protestantes em áreas tradicionalmente católicas. Segundo João Camilo de Oliveira Torres (História das idéias religiosas no Brasil. São Paulo: Grijalbo, 1968, p.279), os protestantes, apesar de numericamente expressivos em muitos lugares, tiveram uma influência extremamente reduzida no plano das idéias e inexistente no plano político. Sua presença mais marcante se deu por meio dos "colégios americanos" batistas e metodistas, que nos primeiros anos da República se estabeleceram em várias cidades do Brasil. aceitos como tais? Nesse sentido, sabe-se que uma das dimensões históricas fundamentais da conformação das práticas religiosas no Brasil diz respeito ao processo de constituição do Estado republicano e às leis penais e sanitárias que visavam disciplinar o espaço público.

Em seu trabalho sobre a criminalização das práticas mágico-curativas no Brasil, Schritzmeyer demonstra que desde os primeiros momentos da constituição da República o combate à feitiçaria e ao curandeirismo fez parte do processo de estabelecimento de uma ordem pública moderna ${ }^{11}$. A jovem República tinha diante de si a difícil tarefa de transformar as naturezas brutas de negros, mulatos e índios (e imigrantes) em uma só sociedade civil, a qual se fundamentaria sobretudo na produção de sujeitos passíveis de serem submetidos à normatividade das leis e na moralidade da religião (cristã). Tratou-se então de absorver e reinterpretar o conhecimento antropológico disponível para discernir o mais claramente possível aqueles que poderiam ser objeto da normatividade legal: feiticeiros, curandeiros, charlatões, exploradores da credulidade pública ou simples vítimas. Como bem demonstrou o trabalho pioneiro de Maggie ${ }^{12}$, tal exercício classificatório foi amplamente empreendido pela jurisprudência brasileira, que, auxiliada pelas autoridades policiais, esquadrinhou os espaços públicos e privados para que os hábitos da população fossem conhecidos, classificados e disciplinados ou tipificados criminalmente.

Se a liberdade religiosa foi cronologicamente a "primeira", a que serviu de modelo para todas as outras formas de liberdade civil, a constitucionalidade jurídica da República se viu às voltas com o problema de separar, no confuso quadro das práticas da população, o que era "religião", portanto com direito a proteção legal, daquilo que era "magia", prática anti-social e anômica a ser então combatida. Em contrapartida, as diversas forças sociais - médicos, advogados, curandeiros, filhosde-santo etc. - procuravam influir como podiam nesses processos classificatórios ao mesmo tempo simbólicos e políticos.

$\mathrm{Na}$ verdade, a extensa agenda do regime republicano para laicizar o Estado e excluir critérios religiosos da cidadania começou por ocupar-se exclusivamente da Igreja Católica. Todas as deliberações legais sobre a religião visavam separar os atos civis e os atos religiosos católicos (matrimônio, batismo, sepultamento, educação, saúde etc.) e fiscalizar o patrimônio da Igreja e das ordens religiosas católicas. Com efeito, desde a Constituição de 1891 se estabelece uma luta contínua entre forças católicas e legisladores em torno de certos privilégios constitucionais da Igreja Católica, sobretudo em relação à obrigatoriedade eà indissolubilidade do matrimônio religioso e ao ensino de religião nas escolas públicas. Outras religiões não foram objeto de debate sistemático, a não ser o protestantismo, que naquele momento já disputava seu lugar no espaço público, sobretudo por meio da atividade educacional ${ }^{13}$.

Portanto, a noção genérica de "religião" a partir da qual se garantiram legalmente a liberdade religiosa e a expressão dos cultos teve como 
matriz o intenso debate jurídico sobre a melhor maneira de regular os bens, as obras e as formas de associação da Igreja Católica. Na formulação de Giumbelli, as disputas em torno da liberdade religiosa que constituíram o espaço civil republicano nunca versaram sobre "qual religião teria liberdade, mas quase sempre sobre a liberdade de que desfrutaria $a$ religião [católica]"14, uma vez que não havia então qualquer outro culto estabelecido, nem se concebiam outras práticas populares como religiosas. A Igreja Católica temia a influência do positivismo e das ideologias secularizantes e agnósticas sobre a nova constitucionalidade do regime republicano.Assim, começou desde cedo a se mover em diversas frentes, procurando influenciaros meios pensantes, os escalões governamentais eas elites por meio da criação de colégios católicos ${ }^{15}$. Em sua tentativa de "cristianizar" a Constituição, a Igreja apoiava-se no exemplo norte-americano: “Como aos americanos, nos assiste a nós o 'jus' de considerar o princípio cristão como elemento essencial e fundamental do direito brasileiro", escrevia em 1931 o pensador católico Tristão de Athayde, citando Rui Barbosa ${ }^{16}$.

Mas se religião consistia consensualmente apenas naqueles cultos praticados pela Igreja Católica, como regulamentar as outras práticas que se expressavam no espaço público? A Constituição de 1891, ao dissolver o vínculo entre Igreja e Estado, suprimiu as subvenções oficiais, mas autorizou toda confissão religiosa a associar-se para esse fim e adquirir bens. Impediu no entanto a institucionalização de associações religiosas em templos ou igrejas, atribuindo-lhes o mesmo estatuto de outras entidades da sociedade civil ${ }^{17}$. Assim, ao longo do processo de institucionalização coube a essas organizações o ônus de demonstrar ao Estado que não representavam uma ameaça à saúde e à ordem pública, ainda que praticassem curas, danças e batuques - e elas o fizeram argumentando que essas práticas deviam ser consideradas religiosas.

Giumbelli afirma que o próprio processo repressivo operante entre 1920 e 1940 teria contribuído para o reconhecimento do estatuto religioso das práticas espíritas, que no início do século XX não tinham a menor pretensão de sefazer reconhecercomo religião ${ }^{18}$. No entanto, ao propagar suas atividades de assistência aos necessitados em "gabinetes clínicos", os espíritas desafiaram um dos pilares da ordem pública urbana: o controle da saúde pública mediante o cerceamento do exercício ilegal da medicina ${ }^{19}$. Ao examinar casos de denúncias nesse sentido julgados nos tribunais, o autor aponta que se travou um debate em torno das formas legítimas e ilegítimas de praticar o espiritismo cujo fulcro era a oposição entre religião e magia (espiritismo como doutrina e como curandeirismo), substrato da distinção entre crença e exploração da credulidade pública ${ }^{20}$. A descriminalização da mediunidade e das práticas curativas a ela associadas será resultante de um processo de transformação do espiritismo em uma forma de culto religioso. Se o médiuméum crente (nos espíritos que dão assistência e curam), não há em seu ato nenhum estelionato, visto que se trata de um rito religioso, instrumento da ação divina.
[14] Giumbelli,Ofim da religião,op.cit., p. 249 .

[15] Cf. Lustosa, Oscar F.A Igreja Católica no Brasil República. São Paulo: Paulinas, $1991, \mathrm{pp} \cdot 45,47$.

[16] Apud Cifuentes, Rafael L. Relações entre a Igreja e o Estado. Rio de Janeiro: José Olympio, 1971, p. 241.

[17] Cf. Giumbelli, O fim da religião, op. cit., p. 252.

[18] Giumbelli, op.cit., p.122.

[19] No início do século XX a política pública de saneamento foi fundamental para viabilizar a vida urbana. Essa política, cujo paradigma foi a colaboração entre o prefeito do Rio de Janeiro, Pereira Passos, e o sanitarista Osvaldo Cruz durante a Presidência de Rodrigues Alves (1902-06), abrangeu várias dimensões: a remodelação urbana, com abertura de avenidas, reforma do porto e desativação de cortiços; a mudança de hábitos da população mediante a proibição de certas atividades em locais públicos, tais como venda de miúdos e ordenha de vacas, urinar e cuspir na rua $e$ algumas diversões populares; a reorganização dos serviços sanitários, que ganharam maior poder de fiscalização e repressão sobre as condições de higiene e as práticas curativas irregulares. É nesse contexto que se produz a figura jurídica do "charlatanismo" (cf. Giumbelli, op.cit., p. 135).

[20] Essa oposição entre crença e credulidade remonta historicamente às noções de idolatria e feitiçaria mobilizadas pelos missionários católicos na América e naÁfrica para combater as "falsas crenças" encontradas nos ritos nativos. A antropologia evolucionista absorveu essa categorização ao identificar a superstição como falso racionalismo causal. A crítica iluminista à religião fixou na literatura filosófica e ensaística a idéia de que a religião é uma forma de ludibriar as consciências e a magia uma forma de fascinar os crédulos. 
[21] Negrão,op.cit.

[22] Ortiz, Renato. A morte branca do feiticeiro negro. Petrópolis: Vozes, 1978.

[23] Maggie,op.cit., p. 24

[24] Giumbelli,op.cit., p. 275.
[25] Maggie (op. cit., p. 24) enfatiza que os processos penais no Rio de Janeiro não se referiam à repressão a cultos, mas à necessidade de identificar feiticeiros e puni-los.
Processos muito semelhantes constituíram o estatuto religioso da umbanda em São Paulo no período 1920-50. Também organizados como associações civis para se proteger das sanções legais, os terreiros foram pouco a pouco assumindo estatuto de religiões, mas para tanto abrigaram-se sob a rubrica do espiritismo, cujas práticas eram mais facilmente aceitas como religiosas do que aquelas de origem africana, marcadas pela idéia de magia. Em seu trabalho sobre a institucionalização da umbanda em São Paulo, Negrão relata que entre 1920 e 1940 as associações umbandistas eram registradas em cartório como espíritas, pois só assim podiam exercer publicamente suas atividades sem sofrer perseguição policial ${ }^{21}$. Assim, a umbanda não emerge desde o primeiro momento como uma religião sincrética que respondia a um tipo peculiar de sociedade - urbana, de classe e individualista -, como pretende a interpretação de autores como Ortiz ${ }^{22}$. Negrão prefere uma análise menos culturalista e reificadora, tomando as relações conflituosas no campo umbandista entre os centros (interessados em seu sucesso prático por meio dos recursos mágicos) e as federações (interessadas em proteger certas práticas da repressão policial e torná-las aceitáveis para a sociedade envolvente) como fatores que promoveram as variadas formas religiosas que essas práticas acabaram por assumir. Foram portanto os próprios mecanismos reguladores criados pelo Estado republicano que constituíram arranjos religiosos como a umbanda, como aponta Maggie ${ }^{23}$.

De acordo com Giumbelli, a diferença entre as práticas tipificadas como "curandeirismo" ou "feitiçaria" e as práticas genericamente tratadas como espíritas pode ser explicada pela divisão de competências entre os aparelhos médico e judiciário, o primeiro responsabilizando-se pela autuação dos crimes contra a saúde pública e o segundo lidando com o controle da desordem pública e as acusações de feitiçaria ${ }^{24}$. No interior desse quadro legal, as diferentes associações selecionavam estrategicamente os arranjos rituais que melhor funcionassem para o tenso equilíbrio entre aquilo que devia ser feito para angariar reconhecimento no âmbito local das relações sociais e aquilo que devia ser evitado para não sofrer acusações que pudessem cair na órbita do poder público. Veremos adiante como essa tensão permanente entre os interesses particulares e locais relacionados ao "sucesso" de uma casa de culto e as necessidades de legitimidade inerentes às suas variadas formas de publicização (desde autorizações para ocupar espaços públicos até concessões de meios de comunicação) alimentou continuamente as mudanças nas configurações rituais dos diferentes cultos.

Embora todas as práticas de curandeirismo fossem tratadas sob a rubrica genérica de "espiritismo", parecia haver um consenso silencioso de que aquelas associadas aos negros - chamadas genericamente de "macumba", "magia negra", "feitiço" - agravavam o ilícito por implicar benefícios materiais e muitas vezes incidir em crime ou dolo25. A República Velha se encerra com uma generalizada disposição hostil e repressiva contra essas práticas. A partir do Estado Novo a repressão se torna 
mais intensa e, segundo Negrão, mais especificamente voltada para as práticas percebidas como marcadamente negras, associadas ao crime e às drogas ${ }^{26}$. Não é por acaso que em 1931 se cria no Rio de Janeiro a Inspetoria de Entorpecentes e Mistificação, dedicada à repressão ao uso de tóxicos e à prática de sortilégios.

Esse marco jurídico-legal em construção, que procurou categorizare tipificar as práticas populares segundo as necessidades da ordem e da saúde públicas, foi aos poucos sedimentando os parâmetros segundo os quais as próprias práticas puderam se exercer na sociedade civil em construção. As práticas de cura realizadas pelos médiuns acabaram por escapar às condenações legais por terem sido tipificadas como religiosas, enquanto aquelas que derivavam para a órbita policial — passíveis de ser percebidas como desordem pública - foram tipificadas como mágicas. Essa polarização se expressou nas possibilidades de institucionalização disponíveis para as práticas populares: às associações que se registrassem em cartório assegurava-se o caráter de organizações religiosas, de modo que ficavam protegidas da repressão; já as práticas de macumba só podiam ser registradas nas delegacias de polícia.

A ordenação do espaço civil republicano dependeu da capacidade do Estado de reorganizar a vida urbana, regulamentar a ocupação e o uso dos espaços públicos pela população e manter a ordem pública. Mas a promulgação deleis não teve um caráter apenas repressivo ${ }^{27}$.A "religião" não se impôs simplesmente no marco legal de cima para baixo, obrigando toda e qualquer prática a assumi-la como forma de estar na sociedade. Na verdade, a eficácia e a adequação da definição do religioso dependiam da compreensão ou da negociação sobre o sentido dos fenômenos que se pretendia regular. Assim, para combater o que era concebido como crime e manter uma população saudável, o Estado construiu aos poucos uma ordem jurídica negociada a partir dos saberes acumulados pelos "homens da lei" e pelos médicos.

Schritzmeyer e Giumbelli fazem uma análise detalhada das diversas correntes das ciências em formação no período - a antropologia, a medicina e a psicologia - que se ocuparam do problema das práticas mági$\operatorname{cas}^{28}$. Para melhor avaliar os perigos e ameaças inerentes a essas práticas, era preciso conhecê-las de maneira mais aprofundada e rigorosa do ponto de vista da ciência. É interessante notar que o foco da atenção tanto dos estudos médicos quanto dos saberes antropológicos que orientaram as disposições do direito foi o transe mediúnico. Evidentemente, não por acaso:era preciso decidir o grau de tolerância possível para com esse fenômeno, uma vez que a criminalização das práticas de curandeiros e feiticeiros dependia da justa qualificação de sua intenção dolosa. Cabia portanto fundamentar melhor as críticas que o saber médico mantinha contra as práticas de transe para definir com mais precisão seu estatuto.

No caso do espiritismo, Giumbelli mostra que o transe fora por muito tempo tratado pelas teorias psiquiátricas e psicológicas como fenômeno patológico ou hipnótico, de modo que fenômenos espíritas
[26] Negrão, op.cit., p. 74 .

[27] Roberto Kant de Lima (A polícia da
cidade do Rio de Janeiro. Rio de Janeiro:
Biblioteca da Polícia Militar, 1994, pp.
56-57) observa que nas primeiras déca-
das da República "ocorreu uma clara
mudança da teoria legal, graças à qual a
polícia passou de uma organização
repressiva e punitiva para uma força
policial 'científica', disciplinadora e
profissional", com funções de vigilân-
cia e prevenção. Assim, era preciso ter
critérios para discernir o potencial de
periculosidade das condutas. Sob a
influência dos conceitos da criminolo-
gia do século XIX, oriundos da "escola
positivista" de autores como Lom-
broso, desenvolveu-sea idéiado "crimi-
noso nato", identificável pelas suas
características anatômicas.

[28] Schritzmeyer, op. cit.; Giumbelli, op.cit. 
[29] Giumbelli, op. cit.

[30] Na primeira metade do século XIX temia-se que as reuniões de negros facilitassem a organização de levantes. Em seu trabalho sobre a capoeira, Letícia Reis observa que as elites, talvez valendo-se do modelo da maçonaria, percebiam os capoeiras como uma espécie de sociedade secreta de negros, cujo posto mais alto pertencia àquele que tirasse mais vidas. Mais para o final do século a capoeira é qualificada pela polícia como "seita sangrenta" (Reis, Letícia. O mundo de pernas para o ar: a capoeira no Brasil. São Paulo: Publisher Brasil, 1997, p.72).

[31] A atitude negativa dos europeus para com a África negra tem raízes antigas. Na doutrina teológica cristã medieval, o mito hamítico, segundo o qual os africanos descenderiam de Ham, o filho mais novo e maldito de Noé, cuja descendência se viu obrigada a migrar para a Etiópia, fixou na consciência do Ocidente a idéia da África como terra do pecado e a do negro como ser degenerado e irredimível.Cf.Dias,Jill R. "África e os africanos no imaginário europeu". In: África nas vésperas do mundo moderno. Lisboa: Comissão Nacional para as Comemorações dos Descobrimentos Portugueses, s/d. como a psicografia e a mediunidade eram explicados pela doutrina da alteração da consciência ${ }^{29}$. Mas na virada do século XX as fronteiras entre hipnotismo e espiritismo foram se tornando cada vez mais nítidas, e cresceu o entendimento de que o hipnotismo devia ser mantido nas mãos dos médicos, pois sua generalização seria uma ameaça à saúde pública. Já no caso das práticas categorizadas genericamente como "macumba" o debate sobre o transe se desenvolveu preferencialmente no campo das ciências jurídicas, relacionando-se a crimes contra pessoas ou patrimônio.

Em meio ao debate sobre o estatuto científico do transe distinguiuse uma forma particular desse fenômeno: a possessão, marcada historicamente pela revolta do negro ${ }^{30}$ e relacionada às práticas de feitiçaria. Ainda que no período colonial a Igreja Católica houvesse tolerado os cânticos e as danças dos negros africanos nos dias santos, os transes eram percebidos como formas de possessão demoníaca e associados à bruxaria conforme o modelo europeu, condenada pela Inquisição ${ }^{31}$. Ora, pode-se afirmar que no contexto cientificista da primeira metade do século XX era mais fácil aceitar como legítima a "mediunidade" - concebida como resultante de processos biopsicológicos universais estudados pelas ciências da mente - do que a "possessão". Na história do Ocidente, essa categoria, vinculada ao repertório cristão, opusera as heresias diabólicas ao êxtase místico, e no caso brasileiro foi associada a sacrifícios de animais, sortilégios e invocações secretas dos negros escravos e libertos. Dessa forma, a matriz cristã contribuiu para a condenação moral desse tipo deformado e invertido de transe, concebido como uma ruptura patológica da individualidade humana.

O modo de conceber o transe operou portanto a partir de duas matrizes: a científica e religiosa. Na chave da ciência, se o transe espírita podia ser concebido como fenômeno universal da mente humana - o hipnotismo - operado por mãos incompetentes, incorrendo no crime de exercício ilegal da medicina (charlatanismo), a "possessão" era da ordem das patologias raciais, podendo levar à degeneração e ao crime. Na chave da religião, se o espiritismo pôde ser aceito como crença foi porque ao atender pobres e doentes não evidenciava intenção de dolo. Já as práticas de negros, uma vez centradas em possessão, batuques e danças "diabólicos", não podiam ser percebidas como ritos religiosos, derivando pois para a categoria inversa, a magia, voltada para o mal e francamente ameaçadora. Assim, pelo menos nas cidades remodeladas sob as políticas higienistas e o controle disciplinar do espaço público, como Rio de Janeiro e São Paulo, as práticas desses agrupamentos de negros foram associadas ao crime e duramente combatidas. A umbanda pode ser compreendida como uma configuração resultante desse processo, mas o seu reconhecimento como religião independente teve de esperar até os anos 1950-60.

O processo que tornou as práticas negras legítimas e as transformou em religiões étnicas resultou de um debate que se desenvolveu ao longo da primeira metade do século XX. Segundo Giumbelli, esse 
debate teve maior impacto nas regiões Norte e Nordeste, onde os intelectuais exerceram maior influência e foram mais felizes em suas tentativas de conferir legitimidade às associações negras ${ }^{32}$. Já nas primeiras décadas do século os candomblés baianos mereceram a atenção dos estudiosos, os quais passaram a ser incorporados a seus quadros mediante títulos honoríficos. Em contraste, como mostra Prandi, na cidade de São Paulo o candomblé não existiu como "alternativa religiosa” pelo menos até a década de 197033 . Pode-se pois avançar a hipótese de que as práticas popularizadas pelas casas baianas tenham sido desde cedo apreendidas pelos estudiosos como religiões primitivas, e não como simples bizarrices ou desvios. Não é por acaso que Nina Rodrigues dá a seu livro de 1900 o título Animismo fetichista dos negros da Bahia.

Se o processo de descriminalização das práticas mediúnicas espíritas se deu mediante um debate médico-jurídico que terminou por produzir uma dissociação entre "fraude" (exercício ilegal da medicina) e "forma de culto" (crença em divindades), no caso da possessão a transformação em rito religioso resultou de um debate entre as ciências médicas e antropológicas. Como se sabe, o paradigma de Nina Rodrigues aprisionara o entendimento desse fenômeno no campo da medicina legal e lhe deu um substrato biológico. Segundo Giumbelli, foi a passagem do modelo biológico para o modelo psicológico e cultural, pelas mãos de Arthur Ramos, que permitiu uma mudança de paradigma. Assim, segundo o autor, duas dinâmicas diferenciadas produziram a mutação da percepção das práticas mediúnicas em práticas religiosas: a lógica legal, que produziu uma matriz de ordenamentos e representação das práticas em função de sua ameaça à ordem pública, e a lógica culturalista, mobilizada pelos intelectuais, que sobretudo a partir da década de 1930 se voltam para as expressões culturais populares de modo a dar forma aos regionalismos 34 .

Mediante esse breve panorama histórico buscamos mostrar que as particularidades da formação do Estado e da sociedade civil no Brasil construíram o pluralismo religioso a partir da repressão médico-legal a práticas percebidas como mágicas, ameaçadoras da moralidade pública. Dessa forma, o modo como hoje se apresentam as "alternativas" religiosas resulta em grande parte de um processo de codificação de práticas no qual médiuns e pais e mães-de-santo levaram em conta os constrangimentos de um quadro jurídico-legal em transformação, os consensos historicamente construídos sobre o que oferece perigo e o que pode ser aceito como prática religiosa, os repertórios de práticas pessoais construídos ao longo de suas trajetórias de vida e as expectativas do público e dos concorrentes. Configuraram-se assim "estilos" de culto derivados de determinadas combinações dos códigos culturais disponíveis. Procuraremos demonstrar a seguir que as noções de "fronteiras" ou "alternativas" religiosas perdem muito de sua consistência empírica quando analisadas desse ponto de vista.
[32] Giumbelli, op.cit.

[33] Prandi,Reginaldo.Oscandomblésem São Paulo. São Paulo: Edusp, 1991, p.15.

[34] Giumbelli, op.cit. 
Vimos que no processo formação do espaço público brasileiro apresentar-se como religião foi a única forma de institucionalização possível para a expressão de práticas que associavam formas heteróclitas de cura e rituais centrados no transe. Aliteratura sobre o tema parece indicar que a combinação de cura e transe produziu formas rituais que na prática tornam muito fluidas as diferenças entre os cultos. Assim, se tomarmos o ponto de vista dos agentes - o modo como se auto-representam e produzem práticas rituais - veremos que os modelos distintivos das religiões (relativos a crenças, ritos, cosmologias, valores e modos de conduta), tais como construídos pela antropologia, perdem grande parte de sua força analítica.

Um dos exemplos mais ilustrativos desse argumento é oferecido por Beatriz Góes Dantas ao relatar o caso de Bilina em seu livro Vovó Nagôe Papai Branco 35, no qual a autora procura mostrar que nos terreiros de Sergipe a "pureza nagô" depende sobretudo das linhas de filiação reivindicadas pelas mães-de-santo. Bilina é neta de uma escrava que se empenhou em fazer com que ela fosse continuadora das tradições africanas cultivadas em seu terreiro na cidade de Laranjeiras, em Sergipe. Sua mãe, crioula, teve um filho com o senhor das terras, e todos os seus outros filhos, inclusive Bilina, o chamavam de "papai branco", eram por ele sustentados e receberam seu sobrenome. Ainda jovem, ela vai trabalhar como doméstica no Rio de Janeiro. Com a morte da avó, abre-se o processo de sucessão de seu terreiro e ela é chamada a ocupar o posto. Sua legitimidade é contestada por outra pretendente, Inácia, que sob a proteção dos velhos africanos se vê como legítima continuadora da tradição, uma vez que Bilina se desligara dos processos tradicionais de aprendizagem desde a sua adolescência. Com efeito, ela ainda não havia sido iniciada. Mesmo assim, o argumento do conhecimento adquirido por revelação e predestinação prevalece sobre o da senioridade, e ela é escolhida como sucessora.

Essas duas fontes de legitimidade produzem combinações diversas de organização de cultos e ritos que estão sempre em disputa em nome da pureza, sob acusações mútuas de feitiçaria. No caso do candomblé de Bilina, a "pureza nagô" se constrói pela supressão de elementos rituais caracterizados pela literatura como tradicionalmente africanos — reclusão na camarinha, raspagem da cabeça, feitura do santo, sacrifício de animais etc. - e pela introdução de outros não pertencentes a esse repertório, como o batismo. Estudos sobre as disputas de legitimidade na umbanda apontam para o mesmo processo. Negrão observa que os terreiros geralmente são constituídos e mantidos por pequenos grupos de parentela, que variam entre dez e trinta pessoas e recebem como clientela um número mais ou menos equivalente ${ }^{36}$. Eles se caracterizam pela fluidez organizacional e pela independência do pai ou mãe-de-santo na definição do rito. Se no caso de Bilina a codificação ritual operava a partir da categoria "pureza nagô", nos casos relatados por Negrão a codificação se 
faz em nome do combate à "mistificação", de que são acusados os que simulariam o transe, e ao "charlatanismo", imputado àqueles que teriam má formação iniciática e explorariam a "credulidade pública". Também aqui as escolhas dos elementos rituais são feitas num contexto de acusações recíprocas, ratificadas pelo sucesso ou fracasso junto a uma clientela.

Esses dois exemplos são ilustrativos do modo como o processo jurídico-legal constituiu os parâmetros dentro dos quais as lógicas de produção de legitimidade podem se mover nas práticas concretas. Evidenciam que os arranjos rituais definidores de um "estilo religioso" próprio a uma casa de culto estão imersos numa lógica concorrencial que se expressa em termos de acusações mútuas de "mistificação" e "charlatanismo" - as mesmas categorias utilizadas historicamente pelo Estado para fundamentar a repressão à feitiçaria. Dessa forma, pode-se afirmar que no plano das relações de concorrência se manifesta o consenso historicamente consolidado no plano das relações jurídico-legais acerca das linhas que separam o interesse público do interesse privado ${ }^{37}$, ou seja, reitera-se a mesma oposição entre religião e magia analisada anteriormente. O depoimento de uma mãe-de-santo registrado por Negrão é bastante ilustrativo nesse sentido:

Quandoagente entraemroncó, agente presta umjuramento que nunca agente vai dizer não aos nossos pais. Eu recebi o decá de mãe-de-santo. Uma semana depois, uma outra filha-de-santo, como recebeu todos os orixás, abriu terreiro. Não recebeu o decá. Então eu acho assim, se fosse uma religião, uma coisa certa, estas pessoas não fariam isso, não existiria tanto charlatão ${ }^{38}$.

A lealdade à mãe-de-santo, garantida pelo decá,é vista como elemento fundamental de legitimidade da prática, isto é, como a linha que separa religião de charlatanismo. Ora, é fácil perceber que o uso da lógica da lealdade como princípio organizador das práticas de um terreiro não permite a expansão de sua combinação ritual para além dos estreitos limites das relações socais mais próximas. Com efeito, alguns exemplos arrolados por Negrão mostram como essa lógica conduz a um contínuo movimento de cisões ${ }^{39}$. Somente quando os agentes são capazes de formular combinações simbólicas e rituais inclusivas e universalizadoras os cultos podem expandir-se para um conjunto abrangente de relações e ganhar maior visibilidade.

Embora a idéia de "continuum religioso" elaborada por Cândido Procópio Ferreira de Camargo tenha captado perfeitamente esse movimento combinatório de códigos espíritas, cristãos e afros que os agentes realizam, situou-o num quadro explicativo temporal e aculturativo da secularização que supunha a passagem histórica da magia para a religião internalizada ${ }^{40}$. Ora, o que podemos ver é a coexistência de múltiplas práticas combinatórias que partilham o mesmo código mas se situam em posições estruturais diversas nessa relação entre Estado, sociedade civil e mundo da vida. Mas qual seria a natureza desse código4?

[37] Aqui estamos operando implicitamente com a dupla dimensão categorial de sociedade em Habermas, como sociedade civil e como mundo da vida. As relações entre esses dois planos não podem ser definidas de antemão, mas assumimos o ponto de vista históricoantropológico que trata a esfera da sociabilidade como esfera pública. Nesse sentido, do mundo da vida em direção à sociedade civil teríamos uma tendência à expansão da publicização, que, apoiada em formas institucionais variadas, vai modelando as opiniões e percepções até se tornar (ou não) propriamente política, na medida em que submete demandas ao Estado (cf. Lavalle, Adrián G. "Jürgen Habermas e a virtualização da publicidade". Margem, no 16,2002).

[38] Negrão,op.cit., grifo nosso. "Roncó": retiro durante o processo de iniciação; "decá”: autorização dada pela mãede-santo para que a filha-de-santo abra seu próprio terreiro.

[39] Eis um exemplo: "Tem outros que começaram aqui, mas quando se viram um pouquinho melhor acham que já podem andar pelo mundo [...].terreiroé como passarinho: ganhou asas, voa" (ibidem).

[40] Camargo, Candido Procópio.Kardecismo e umbanda. São Paulo: Pioneira,1961.

[41] Embora se possa afirmar que alguns códigos religiosos sejam mais universais do que outros (como, por exemplo, a idéia católica de salvação, que inclui todos os homens, em contraposição à figura do filho-de-santo, que inclui apenas o iniciado), não se pode simplesmente deduzir do código religioso o potencial universalizador de uma prática. Na medida em que é da natureza do código combinar-se e ressignificar-se mediante as práticas rituais, o que hoje pode ter alcance local amanhã pode funcionar num sentido generalizador. $\mathrm{O}$ uso da noção de código procura evitar o dualismo implícito na teoria weberiana das religiões, que as tipifica em universais (transformadoras e abstratas) e locais (conformistas e estereotipadas). A noção de código não supõe um conteúdo fixo, já que seu sentido é atualizado na prática. 
[42] Virtude teologal que conduz ao amora Deus e ao nosso semelhante, especialmente os pobres e desprotegidos.

[43] Segundo Emerson Giumbelli (Caridade, assistência social, política e cidadania: práticas e reflexões no espiritismo. Rio de Janeiro: Arquivo Nacional, 1998), foi em nome da "caridade" que os espíritas formularam suas acusações de charlatanismo, supertição e magia contra práticas por eles consideradas ilegítimas. Mas essas práticas foram com o tempo se transformando até chegarem a se identificar, em contexto mais recente, com a noção de "direitos civis".

[44] É interessante observar que enquanto a Igreja Católica, já no final do XIX, começa a estimular no mundo todo a formação científica do médico e da enfermeira católicos, o espiritismo e as religiões não-letradas lançam mão do "maravilhoso" na busca do sucesso dos rituais terapêuticos.

[45] O pentecostalismo está no Brasil desde 1910 com a chegada da Congregação Cristã. Segundo Ronaldo de Almeida (A universalização do Reino de Deus. Campinas: dissertação de mestrado, Unicamp, 1996), na década de 1950 o missionário norte-americano Harold William trouxe a Igreja do Evangelho Quadrangular, e a cura divina tornou-se então um dos eixos principais da pregação do pentecostalismo, facilitando sua expansão. Mas foi na década de 1980 que o pentecostalismo ganhou a visibilidade que tem hoje, não apenas em razão de seu crescimento numérico, mas também pela sua presença na esfera pública e nos meios de comunicação.

[46] Embora praticada abertamente, essa coincidência está longe de ter conquistado legitimidade social, como mostram as acusações de charlatanismo, extorsão, lavagem de dinheiro e enriquecimento ilícito contra a Igreja Universal, freqüentemente veiculadas na imprensa.
No processo histórico de construção da sociedade civil brasileira, os limites do Estado para implementar uma política social e assistencial abrangente o levaram a apoiar-se reiteradamente em acordos com a Igreja Católica. No rastro dessa "devolução" das funções seculares do Estado para a Igreja, organizou-se no espaço público todo um conjunto de práticas de assistência no campo da saúde que se apropriou do código cristão da "caridade" 42 . As associações civis, a começar pelos centros espíritas, lançaram mão da homeopatia e de rituais mediúnicos para, em nome da caridade, proceder ao atendimento terapêutico e à proteção dos necessitados ${ }^{43}$. Mas ao contrário das práticas católicas, organizadas em torno de hospitais, asilos e dispensários e apoiadas na formação científica de seus quadros, os terreiros e centros exerceram suas atividades no mais das vezes no ambíguo campo da oposição magia/religião44. Nesse contexto, "caridade" passa a significar a prática gratuita e desinteressada de ajuda ao pobre - ato religioso de compaixão -, enquanto a "feitiçaria" é seu oposto - ato pecuniário egoísta que engana os crédulos. Assim, cabe a cada liderança das casas de culto ou terreiros definir, na luta pela clientela, a posição relativa de suas práticas nesse espectro.

Os relatos reunidos pela literatura sociológica e antropológica sobre o modo como as lideranças religiosas representam suas práticas e as outras indicam que a variação da posição de um grupo em sua relação com o Estado e a sociedade civil relaciona-se diretamente a uma variação na combinação do código "caridade/feitiço": quanto mais pública e abrangente se quer essa prática, mais será acionado o código "religião/caridade"; quanto mais local for ela, mais será acionado o código "magia/feitiçaria". Embora esses códigos pertençam ao mesmo campo das representações coletivamente assimiladas - o campo da religião ou da cultura nacional - o da feitiçaria, talvez porque opere segundo uma lógica na qual "dar para umé tirar de outro", não tem a mesma capacidade de universalização das relações que o código cristão da caridade.

\section{A INVERSÃO PROTESTANTE}

No campo protestante, a noção de "assistência social" também opera na chave da caridade, mas a variação da Igreja Universal do Reino de Deus me parece ser a mais interessante 45 . Sua originalidade nesse campo reside no fato de ter produzido uma dupla inversão dos termos até aqui analisados: por um lado, seus ritos generalizaram a "feitiçaria" no espaço público por via dos meios de comunicação; por outro, fizeram coincidir caridade e prosperidade econômica ${ }^{46}$. Em suas práticas rituais mais importantes, a Igreja Universal recupera e ressignifica duas categorias clássicas do cristianismo: o exorcismo e o donativo em dinheiro. 
Sabe-se que na tradição cristã o grande adversário da religião é Satã, que encarna todos os obstáculos à salvação. Ao assumir-se historicamente como a verdadeira religião, o cristianismo assimilou como demônios todas as divindades de outros credos. Assim, o maior crime de Satã é perpetuaro paganismo. A prova mais segura da verdade da fé cristã está no poder concedido a seus fiéis de exorcizar os possuídos pelos demônios 47. O exorcismo dos "demônios pagãos" personificados nos exus constitui um dos principais momentos dos ritos da Igreja Universal48. Mediante esse procedimento, ela anexa todo o repertório disponível de códigos mediúnicos e os universaliza na idéia mais abstrata de Mal. A transmutação de exus em personificação do Mal e sua expulsão deslocam a lógica simbólica do feitiço - que opera no plano das relações entre homens e deuses - do domínio do humano para o da luta cósmica entre o Bem e o Mal: o exorcismo combate tudo aquilo que afasta os homens da vida eterna no Paraíso. Anexada dessa forma ao código cristão da salvação, a feitiçaria deixa de ser uma prática acusatória pontual, exibindose na cena pública como rito religioso e prática desinteressada.

Um outro deslocamento simbólico importante refere-se à oferta em dinheiro. No caso dos terreiros, a "cobrança pelos serviços" personaliza o pagamento, tornando-o suspeito de interesse privado e de exploração dolosa. No caso da Igreja Universal, esse ato é entendido como "doação": uma demonstração de fé endereçada diretamente a Deus para desafiá-lo. A oferta instaura uma aliança entre Deus e o homem, pela qual aquele fica obrigado a uma imediata restituição. $\mathrm{Na}$ interpretação de Gomes, Deus não pode subtrair-se ao jogo, de modo que "a oferta cria uma pretensão que deve, impreterivelmente, ser alcançada, um direito" 49 . Enquanto nos terreiros o dinheiro deve permanecer como um mediador invisível do sacrifício (um meio de aquisição de velas, animais etc. para as cerimônias), no pentecostalismo da Igreja Universal o próprio dinheiro é o objeto de sacrifício. Com efeito, é esse o nome que se dá à oferta. Mas sacrificar dinheiro e bens significa na verdade colocá-los em risco, ou aceitar o risco da privação apostando na restituição divina: quanto maior o risco, maior a fé e conseqüentemente maior a recompensa. Segundo Gomes, na Igreja Universal é a idéia de posse que dá sentido ao exorcismo e à oferta. Prosperidade, saúde e amor são um destino humano por vontade de Deus; assim, "tomar posse" significa realizar aquilo para o que se está destinado. A Igreja viabiliza a reintegração de posse a que os homens têm direito ao "desamarrar" aqueles que estão desprovidos das bênçãos divinas em razão da ação perturbadora dos demônios.

Aidéia de troca implícita nessas relações entre homens e Deus é pois ressignificada. Nos códigos afros são ofertados presentes — velas, bebidas, cigarros, comida - para agradar os deuses, torná-los generosos com os homens. Essa circulação demasiadamente humana de bens, o caráter metonímico do sacrifício, que muitas vezes implica a morte de animais, sofre a suspeição de animismo ou selvageria.Já o modo sacrifi- 
[50] Com o desenvolvimento das teorias matemáticas sobre a probabilidade, o risco torna-se potencial objeto de medida. Nesse sentido, torna-se instrumento da economia para cálculo de investimentos financeiros. Ligada ao sentido do cálculo das possibilidades, a idéia de risco associou-se à idéia de "escolha racional", já que se supõe possível calcular as possibilidades de perdas e ganhos.
[51] A Constituição de 1891 reconheceu apenas o casamento civil, mas a de 1946 reintroduziu o reconhecimento dos efeitos civis do casamento religioso e a de 1988 reiterou essa condição. cial que o dinheiro assume nos ritos da Igreja Universal retira do sacrifício seu caráter violento e bárbaro e o transmuta em uma abstrata relação de risco, como em um investimento econômico5 ${ }^{\circ}$. Nesse processo de universalização, o dinheiro se desfetichiza e ao mes mo tempo a noção de caridade cristã como proteção aos pobres concebida em termos comunitários se transforma num direito individual dos pobres. Sacrificar ritualmente o dinheiro (reduzir incertezas mediante risco) e exorcizar o feitiço (indexar os demônios pagãos à idéia de salvação) são formas de discursos práticos que negociam com outras proposições, o que repõe em jogo as fronteiras entre magia e religião.

\section{PLURALISMo e Religiosidade}

Se as "fronteiras" religiosas perdem muito de sua consistência empírica quando analisadas do ponto de vista da luta concorrencial entre os agentes, quando o foco se desloca para a experiência dos freqüentadores e usuários das casas de culto elas simplesmente parecem não existir. Buscamos demonstrar acima que o campo dessas práticas foi ganhando forma e inteligibilidade no interior de um universo jurídicolegal que definiu o "religioso" em referência ao católico. Nesse sentido, a "crença em Deus", unidade mínima do que pode ser aceito como "religião", é um referente universal de todas as práticas: "Todas as religiões são boas porque todas conduzem a Deus", diz um lema kardecista — ou, diríamos nós, todas as religiões são percebidas como religiões porque supõem a crença em Deus.

Já está assentado na literatura sobre o tema o fato de que tanto pais e mães-de-santo como espíritas geralmente se auto-representam como católicos. No entanto, se toda combinação de práticas rituais pode ser reconhecida como religiosa ao apresentar-se como forma de expressão de crenças, ritos civis como batismo, casamento e sepultamento ainda são amplamente reconhecidos como monopólio da Igreja Católica ${ }^{51}$. Esse duplo substrato - a fé em Deus e os ritos civis - faz do catolicismo a língua universal da tradução de qualquer prática em rito religioso e o referencial de uma publicização legítima. Essa convertibilidade, percebida quase como natural, é potencializada pelos vínculos históricos que, como vimos, ligaram tendas de umbanda, roças de candomblé e centros espíritas no processo histórico de suas institucionalizações como religiões.

Observando esse mesmo processo do ponto de vista dos freqüentadores, percebe-se com clareza ainda maior que o "pluralismo religioso", pelo menos no que diz respeito ao espectro dos códigos afros, espíritas e cristãos, constitui um mesmo sistema de combinações rituais. Em sua descrição do campo religioso brasileiro, Brumana observa que os indivíduos freqüentam livremente todo tipo de "religião", de acordo com suas necessidades e problemas conjunturais. Como diz um de seus informantes, "todas as religiões são boas, mas cada qual para uma ocasião": 
Para alguém que não tem problemas na vida, a melhor é a católica. [...] para alguém com problemas financeiros a melhoré a dos crentes porque eles se ajudam como irmãos. [...] para os que sofrem de enxaqueca a melhor religião éo espiritismo. [...] Se Deus deixar, quando se está completamente curado, voltase para o catolicismo ${ }^{52}$.

Esse depoimento é paradigmático, pois permite perceber que as noções de "devoção" e "conversão", que orientaram grande parte das análises sobre os fenômenos religiosos, não descrevem com precisão o que ocorre no campo das práticas. Nesse campo, os "adeptos" não são sujeitos de "convicções" religiosas e a mudança de religião não pode ser tratada em termos de "conversão". Essa noção, como vários autores já apontaram, projeta sobre os diferentes cultos o modelo protestanteweberiano como forma doutrinária internalizada 53 . Ora, o depoimento demonstra que o indivíduo combina matrizes simbólicas disponíveis de maneira estratégica e contextual, sem que isso implique mudança de ordem subjetiva. Depoimentos coletados por Negrão também expressam essa percepção:

Eu era mesa-branca [e] com quatorze anos passei para umbanda porque a mesa-branca foi muito fraca para os meus orixás [...].

Minha umbanda é kardecista porque eu sigo mais ou menos o ritmo [do kardecismo ], só que aqui a gente só tem uma diferença:se usa velas, tem as imagens $e[. .$.$] todo mundo usa umas saias bem compridas 54$.

Chama a atenção nesses depoimentos o modo como são pontuadas as diferenças entre os cultos: presença/ausência de velas, roupas, um ou outro orixá. Fica evidente que os arranjos religiosos se fazem no plano ritual e não no doutrinário. A circulação entre tendas, templos e terreiros depende da avaliação conjuntural da força relativa dos ritos no que diz respeito às questões de saúde e prosperidade. A "inversão protestante" situa o neopentecostalismo nesse mesmo campo de transformações. Sua força simbólica reside, como vimos, na capacidade de alargar a definição cristã do religioso de modo a incorporar códigos afros. Nessa operação ritual a vitalidade dos poderes da "feitiçaria" é ao mesmo tempo conservada e neutralizada.

O privilégio da dimensão ritual na experiência religiosa nos permite supor que a circulação entre cultos não necessariamente põe em jogo processos de desenraizamento e individuação de sujeitos, implícitos na teoria weberiana da conversão. Com efeito, análises recentes do pentecostalismo têm enfatizado sua dimensão mais performática que doutrinária. Observando rituais como o de "louvor" e o da glossolalia na Igreja Universal, Corten conclui que eles contém um efeito estético no qual se produz um "exorcismo" da pobreza ${ }^{55}$. Trata-se de enunciados sem conteúdo informativo, que dependem da qualidade da performance para se tornar aceitáveis e convencer o público de sua eficácia. A
[52] Brumana, Fernando G. "Spirits from de margins: umbanda in São Paulo". Uppsala Acta Universitatis Upsaliensis/Uppsala Studies in Cultural Anthropology, no 12, 1987, p. 28.

[53] Ao analisar processos de conversão na África, Robert W. Heffner (Conversion to Christianity: historical perspectives on a great transformation. Berkeley: University of California Press, 1993, p. 15) apontou a insuficiência do modelo weberiano, que tende a supor uma homologia entre o que ele chama de "racionalização cultural" (sistematização e formalização de verdades culturais à luz de valores e ideais, ou religião como doutrina) e "racionalidade da experiência" (internalização de doutrinas ou verdades prefiguradas).

[54] Negrão, op. cit., pp.310,315.

[55] Corten, André. Os pobres e o espírito santo:o pentecostalismo no Brasil. Petrópolis:Vozes, 1996, p. 151. 
[56] Maximiano, Maria Aparecida. Os procedimentos argumentativos nos discursos da Igreja Universal do Reino de Deus. São Paulo: dissertação de mestrado, Departamento de Lingüística da USP, 2002. importância das configurações rituais na experiência religiosa confere a essas práticas uma fluidez e uma volubilidade que são captadas de maneira muito imprecisa pela idéia de "alternativas religiosas" entendida aqui como conjunto distintivo de religiões cujos universos de valores e práticas estão em relação concorrencial. Com efeito, do ponto de vista da experiência a pessoa não se percebe "mudando de crença", mas operando repertórios adequados a situações conjunturais ou a escolhas mais ou menos estéticas.

A recente expansão da Igreja Universal do Reino de Deus não parece ter modificado os termos da equação. Análises como a de Maximiano mostram a importância do cenário e da oratória nos modos de persuasão simbólicos desse culto, em que o conteúdo dos discursos cedelugar ao tom de voz, ao ritmo da frase e ao gesto ${ }^{56}$. A dimensão performática desse culto o situa na cadeia das variações rituais que partilham os mesmos códigos: a diferença aqui está em sua capacidade renovada de indexar ao religioso códigos percebidos como mágicos. O catolicismo havia feito isso no passado por meio da categoria "superstição": crenças "falsas" a corrigir. Com o declínio da figura do demônio na cosmogonia católica e o deslocamento da idéia de mal para o mundo social, o neopentecostalismo pôde recuperar para si o ritual exorcista e indexar os códigos afros à idéia de mal.

\section{CONCLUSões}

Em face das disputas históricas que marcaram as distinções entre o religioso e o mágico no país, podemos perceber como a idéia weberiana de "secularização" é insuficiente para explicar a construção do espaço público no Brasil. A instauração de um Estado secular produziu ao mesmo tempo um espaço civil e novas religiões. A demarcação das fronteiras religiosas foi resultado de um processo histórico de diferenciação entre magia e religião, e seus limites se deslocam continuamente em função dos consensos produzidos a cada momento. O pluralismo religioso, convencionalmente compreendido como tolerância com a diversidade de cultos e como respeito à liberdade de consciência, se constituiu às avessas no Brasil: não foi fundamento do Estado moderno, mas seu produto.

Ainda que para determinadas práticas o "tornar-se religião" tenha representado a única forma socialmente legítima de existirem no espaço público, não se pode inferir que essas práticas assumiram em seu modus faciendi a forma daquilo que a literatura especializada convencionou chamar de "religião": um sistema doutrinário de crenças em deuses. Com efeito, as formas de crença supostas pela literatura - subjetivadas e racionalizadas - não parecem dar conta do modo como os sujeitos circulam entre casas de culto e se apropriam das práticas rituais disponíveis. As lutas pela legitimidade social lançam mão de códigos compartilhados (o jogo entre caridade e feitiço) a fim de produzir poder social e 
simbólico em cada situação. Ocorre porém que esses códigos parecem funcionar com sinais trocados: quanto maior o poder social (investido no ideal da caridade/gratuidade), menor o poder simbólico (força mágica do feitiço/dinheiro).A recente expansão do neopentecostalismo não modificou os termos dessa equação; antes, produziu uma equação com maior capacidade de generalização.

Embora tenha perdido legitimidade para organizar o mundo público, a Igreja Católica foi uma importante matriz no processo de constituição da esfera pública no Brasil. Ela não deixa de ser Igreja depois da República: ainda hoje é legitimada como responsável pelos ritos civis socialmente válidos. Assim, embora a oposição entre crença e superstição não possa servir de fundamento para o controle das práticas rituais não-católicas, a distinção entre sacramento e rito ainda é reconhecida como perfeitamente legítima. Na medida em que estão na base da formação de nossa esfera pública, alguns códigos católicos ainda são percebidos como aqueles aceitáveis para expressar ou demandar algo no espaço público. Ainda reverberam em nossa idéia de bem comum associações entre religião e verdade, de um lado, e entre feitiçaria e falsidade, de outro.

Segundo Corten, a glossolalia pentecostal constitui enunciados que ainda estão fora da linguagem política reconhecida, mas quando certas narrativas começarem a se impor, tais como a "teologia da prosperidade", essa condição pode mudar 57 . O uso intensivo dos meios de comunicação pelos pentecostais e seus ritos performáticos, como o louvor, o testemunho e o exorcismo, produzem um discurso que não funciona nem como verdade nem como normatividade, mas como miseen-scène da soberania divina, da força da fé. Se a "teologia da libertação" produziu a categoria do pobre como ator político na cena pública (ainda que a libertação projete a salvação para fora da história), a "teologia da prosperidade" produz o pobre como ator econômico e o torna responsável por sua própria salvação ${ }^{58}$. Seu modo de ritualizar o dinheiro (via sacrifício) e fortalecer a eficácia da ação (via incorporação da feitiçaria no exorcismo) lhe dá uma amplitude discursiva que a teologia da libertação não foi capaz de alcançar por se recusar a essa negociação com as "heresias" populares.

Nessa nova configuração, os códigos referentes à saúde e à prosperidade, como uma ética do mundo dos pobres, têm apresentado grande capacidade de mobilização. Esse capital social tem ampliado as manifestações públicas dessas práticas, cujos ritos conquistam estádios de futebol, televisões e diversas instituições públicas. Mas sua potencialidade propriamente política, isto é, sua capacidade de constituir atores organizados que demandem junto ao Estado uma regulação específica, ainda não me parece claramente definida — em contraste com a atuação da teologia da libertação nos anos 1970-80, quando esteve na base de inúmeros movimentos sociais organizados. Apesar da crescente presença dos pentecostais na arena política e nos
[57] Corten, op. cit., p. 182. Segundo o autor, a "teologia da prosperidade" consiste basicamente em prosperidade no plano da saúde conquistada pela cura divina, e constitui uma ética do mundo dos pobres (p.155).

[58] Segundo Corten(ibidem), a teologia da libertação, que é uma teologia profética (anuncia o fim do mundo e a salvação), constrói a categoria "pobre" como grito de indignação e garantia divina de salvação, produzindo assim uma emoção para os pobres, enquanto a teologia da prosperidade produziria uma emoção dos pobres.

[59] Em 1996 os pentecostais elegeram dezoito deputados federais, os quais, associados aos dezesseis eleitos pelos protestantes históricos, formaram um bloco conhecido como "bancada evangélica”. Graças ao apoio que deram ao governo Sarney, conseguiram várias concessões de emissoras de rádio e televisão. Cf. Pierucci, Antônio Flávio. 
"Representantes de Deus em Brasília: a bancada evangélica na Constituinte". Ciências Sociais Hoje, 1989 .

Recebido para publicação

em 15 de dezembro de 2005.

NOVOSESTUDOS

CEBRAP

74 , março 2006

pp. $47-65$ meios de comunicação59, o mesmo não parece acontecer com a "teologia da prosperidade" e seus ritos de exorcismo. Mas não resta dúvida de que, pelo menos entre as camadas mais pobres, emerge uma forma de conceber a inclusão e a "boa vida" cuja influência na esfera pública ainda não foi corretamente avaliada.

PAUla Montero é professora do Departamento de Antropologia da USP e pesquisadora do Cebrap. 